\title{
Overall Performance, Carcass Yield, Meat Safety Potentials and Economic Value of Heat-Stressed Broilers Fed Diets with Balanced Electrolytes
}

\author{
Ibukun Olukorede Popoola ${ }^{1,2^{*}}$, Oluwabukola Rashidat Popoola1,2, Akinyemi Alaba Adeyemi ${ }^{1}$, \\ Oluwatobi Matthew Ojeniyi', Ibikunle Funsho Olaleru' ${ }^{1,3}$, Femi Joshua Oluwadele1, \\ Ezekiel Olukunle Akinwumi ${ }^{1}$ \\ ${ }^{1}$ Department of Animal Science, University of Ibadan, Ibadan, Nigeria \\ ${ }^{2}$ Agricultural Research and Biometrics Department, Thisavrous Pyrgos Integrated Resources, Ibadan, Nigeria \\ ${ }^{3}$ Farming System Research Program, National Root Crops Research Institute, Umudike, Nigeria \\ Email: *popoolaibukun@yahoo.com
}

How to cite this paper: Popoola, I.O., Popoola, O.R., Adeyemi, A.A., Ojeniyi, O.M., Olaleru, I.F., Oluwadele, F.J. and Akinwumi, E.O. (2020) Overall Performance, Carcass Yield, Meat Safety Potentials and Economic Value of Heat-Stressed Broilers Fed Diets with Balanced Electrolytes. Food and Nutrition Sciences, 11, 615-628. https://doi.org/10.4236/fns.2020.117044

Received: June 9, 2020

Accepted: July 6, 2020

Published: July 9, 2020

Copyright $\odot 2020$ by author(s) and Scientific Research Publishing Inc. This work is licensed under the Creative Commons Attribution International License (CC BY 4.0).

http://creativecommons.org/licenses/by/4.0/

\begin{abstract}
Tropical regions across the globe are characterized by an annually prolonged hot weather conditions that showcase limiting production efficiency in livestock industry, as domesticated animals leave the zone of maximum comfort, under heat stress, with death and reduced carcass yield accompanying the subsequent alteration in body chemistry and behavior. However, pen house orientation, cooling systems, genetic modification and different dietary manipulations have been employed in poultry industry, but many of such did not account for the body's acid-base equilibrium and the potentials of aggregate levels of dietary electrolytes in enhancing carcass yield of broilers under severe heat stress conditions. Therefore, this study was conducted to investigate the effects of different electrolyte-balanced diets on overall performance, carcass yield, meat safety potentials and economic value of heat-stressed broilers reared for five weeks. Arbor Acre broiler chicks $(\mathrm{n}=300)$ were randomly allotted to diets with aggregate electrolyte balance of 210 (T1), 240 (T2), 270 (T3), 300 (T4), 330 (T5) and 360 (T6) mEq/Kg, in a completely randomised design. On day 35, birds whose weights were closest to the mean class weight were selected from each replicate pen for carcass yield assessment. Also, data on performance and cost-benefit analysis were analysed using descriptive statistics and ANOVA at $\alpha=0.05$. Electrolyte-balanced diets though contained salts that presumably could have improved satiety, yet they do not enhance appetite in heat-stressed broilers. However, dietary protein efficiency was enhanced at an electrolyte balance levels of 240 and $270 \mathrm{mEq} / \mathrm{kg}$, which translated into increased body weight gain. Weights of primal parts of birds on $270 \mathrm{mEq} / \mathrm{kg}$ DEB were highest at 35 days. Feed cost values (per kilo-
\end{abstract}


gram weight gain) of rations with $240 \mathrm{mEq} / \mathrm{kg}$ and $270 \mathrm{mEq} / \mathrm{kg}$ DEB were lower and showcased promising economic buoyancy to both rural and commercial poultry farmers, while ensuring a high food safety standard under tropical conditions.

\section{Keywords}

Broilers, Carcass, Dietary Electrolytes, Heat Stress, Meat Safety, Tropical Agriculture

\section{Introduction}

The fast growth of the poultry industry has been attributed to poultry's good converting ability of feeds into useable protein in meat and eggs coupled with the relatively high return on investment as the production cycle is relatively short, and an undue tie up of capital over a long period is prevented [1] (Ojo, 2003). Also, poultry meat is very tender and has gained consumers' acceptability world-wide. However, it has been shown that feed cost constitutes about $80 \%$ of the total operating cost in the poultry industry, as there has been, in recent years, a rapid increase in the prices of feed ingredients that have affected net return from poultry industry (Ohajianya et al., 2013) [2]. According to Muriu et al. (2002) [3], the economization of feed cost using cheaper, but highly nutritive unconventional feed resources and additives is an important aspect of commercial livestock production. Oyewole et al. (2013) [4] opined that one of the ways of reducing the cost of poultry feeds and improving its efficiency is by preparing vitamin-mineral premix from materials sourced locally. However, St-Pierre et al. (2003) [5] reported that heat stress resulted in estimated total annual economic loss to the US livestock production industry of $\$ 1.69$ to $\$ 2.36$ billion; and from this total, $\$ 128$ to $\$ 165$ million occurs in the poultry industry.

Rostagno (2009) [6] noted that there is increasing evidence to demonstrate that heat stress has a significant deleterious effect on food safety through a variety of potential mechanisms. However, while there is evidence linking heat stress with pathogen carriage and shedding in farm animals, the mechanisms underlying this effect have not been fully elucidated. Environmental stress has been shown to be a factor that can lead to colonization of farm animals by pathogens, increased fecal shedding and horizontal transmission, and consequently, increased contamination risk of animal products (Verbrugghe et al., 2012) [7]. Sohail et al. (2012) [8] reported that broilers subjected to chronic heat stress had significantly reduced feed intake, lower body weight, and higher feed conversion ratio at 42 days of age. The body weight changes were explained by Geraert et al. (1996) [9] who indicated that endocrinological changes caused by chronic heat stress in broilers stimulate lipid accumulation through increased de novo lipogenesis, reduced lipolysis, and enhanced amino acid catabolism. However, chronic heat stress negatively affects fat deposition and meat quality in broi- 
lers, in a breed-dependent manner (Lu et al., 2007) [10]. Imik et al. (2012) [11] demonstrated that heat stress is associated with depression of meat chemical composition and quality in broilers. Zhang et al. (2012) [12] demonstrated that chronic heat stress decreased the proportion of breast muscle, while increasing the proportion of thigh muscle in broilers.

Animal infections have been attributed to effects of stress-associated hormones and mediators on the immune system. However, Lyte (2004) [13] noted that the theories of microbial endocrinology have showcased a direct effect of stress-associated hormones and mediators on bacterial pathogens. Bacteria, such as Salmonella and Campylobacter, are capable of exploiting the neuroendocrine alterations due to the stress response in the host to promote growth of pathogens. Therefore, it is of great importance to be aware that heat stress can potentially alter the host-pathogen interaction (Freestone et al., 2008) [14]. However, Popoola et al. (2020) [15] have noted that dietary manipulation, such as the use of an ideal dietary electrolyte balance (DEB) in poultry rations would significantly ameliorate the adverse effects of heat stress prevalent in the tropics. Mongin (1981) [16] reported optimal chick performance with DEB of around 250 $\mathrm{mEq} / \mathrm{kg}$. Similarly, Borges (2001) [17] noticed best broiler performance with DEB varying from 186 to $250 \mathrm{mEq} / \mathrm{kg}$. In an experiment conducted to evaluate the different sources of dietary electrolytes, Ahmad et al. (2005) [18] observed significantly high carcass weight and dressing percentage in heat stressed broilers fed diets supplemented with sodium bicarbonate and ammonium chloride supplements at fixed DEB value of $250 \mathrm{mEq} / \mathrm{Kg}$. Therefore, this study was conducted to investigate the effects of different electrolyte-balanced diets on overall performance, carcass yield, meat safety potential and economic value of heat-stressed broilers reared under severe heat stress conditions.

\section{Materials and Methods}

The study of evaluating the carcass and economic yield of heat-stressed broilers was carried out at the Teaching and Research Farm, University of Ibadan, Nigeria, after the experimental protocol was reviewed and approved by the Institutional Animal Care and Use Committee; and the Agricultural Biochemistry and Nutrition Unit of the Department of Animal Science. The institution is located on latitude $7^{\circ} 20^{\prime} \mathrm{N}$, longitude $3^{\circ} 50^{\prime} \mathrm{E}$, and $200 \mathrm{~m}$ above sea level, in a tropical rain forest vegetation zone. A total of 300, one-day old unsexed Arbor Acre broiler chicks were randomly allotted to six dietary treatments (mEq/Kg: 210, 240, 270, 300, 330, 360 DEB) with five replicate groups in a Completely Randomized Design (CRD). Feed grade potassium chloride and sodium bicarbonate, and the inherent potassium, sodium and chloride ions in feed ingredients were the electrolyte sources computed for determining the aggregate DEB using the equations derived by Popoola and Iyayi (2018) [19], which were based on assumptions put forward by Popoola et al. (2020) [20] for an ideal DEB.

The derived equation of DEB is 


$$
\Sigma \mathrm{DEB}=\Sigma\left(\mathrm{Na}^{+}+\mathrm{K}^{+}\right)-\Sigma \mathrm{Cl}^{-}[y][c]
$$

where $[y]=$ mineral sources

and $[c]=$ other macro ions (Ca, Mg, P, S etc.) held constant.

$$
\Sigma \mathrm{DEB}=\iota \mathrm{DEB}+\varepsilon \mathrm{DEB}
$$

where $\Sigma \mathrm{DEB}=$ Aggregate $\mathrm{DEB} ; \mathrm{DEB}=$ Inherent $\mathrm{DEB}$ in rations and $\varepsilon \mathrm{DEB}=$ DEB in Electrolyte sources.

Data on feed intake was determined by giving a known quantity of feed to the birds and subtracting the left over for a given period from the quantity supplied. This difference was divided by the number of birds in a replicate group to estimate the feed intake per bird. Body weight gain of birds was determined by subtracting the initial weight for each week from the final weights with the aid of sensitive weighing scale. The feed conversion ratio was calculated by dividing the mean feed intake with the mean body weight gain. Drinking water was supplied to broilers as described by Popoola et al. (2019) [21]. On day 35, birds were selected from each replicate pen whose weights were closest to the mean class weight for carcass yield assessment. Weights of internal organs were harvested same day that the carcasses were obtained. Prices of experimental diets were calculated according to the prices available for ingredients in local markets in Nigeria during the year 2019. Assay was conducted for sodium and potassium (Flame spectrophotometer), and chloride (titration) in diets fed to broiler chickens at different phases of growth (Lacroix et al., 1970) [22]. Microbial load in meat and faecal samples were determined by the agar well diffusion method. The analysis was run using the Bismuth sulfite agar which is a type of agar media used to isolate Salmonella species. The agar was prepared for Salmnella growth according to the instructions of the manufacturer. A $1 \mathrm{~g}$ faecal sample from each treatment was weighed and mashed in $9 \mathrm{ml}$ of distilled water to give a uniform mixture. Serial dilution method was used in which $10 \mathrm{ml}$ of $10^{3}$ and $10^{5}$ of each sample was pipette onto a sterile petri dish and the already prepared agar at $45^{\circ} \mathrm{C}$ was poured into it. It was swirled gently for even distribution; the plates were inverted and incubated in an incubator at $38^{\circ} \mathrm{C}$ for 24 hours after which the colonies formed on each media were counted using the visual aid. Data obtained were subjected to descriptive statistics and analysis of variance using SAS package (2012) [23]. Means for treatments in the analysis of variance were compared using Duncan Multiple range test and all statement of significance were based on probability level of 0.05 .

\section{Results}

\subsection{Overall Performance of Heat-Stressed Broilers on Diets with Balanced Electrolytes}

Table 1 shows the chemical composition of dietary treatments fed to heat-stressed broiler chickens for a period of 35 days at starter and finisher phases. Table 2 shows the overall performance of broiler chickens fed diets with different electrolyte balance. Feed intake of heat-stressed birds at 0 to 35 days was not significantly 
Table 1. Chemical composition of experimental diets fed to broiler chickens at starter and finisher phases.

\begin{tabular}{|c|c|c|c|c|c|c|c|}
\hline \multirow{2}{*}{ Period } & \multirow{2}{*}{ Nutrients (\%) } & \multicolumn{6}{|c|}{ Diets (mEq/kg) } \\
\hline & & $210(\mathrm{~T} 1)$ & $240(\mathrm{~T} 2)$ & $270(\mathrm{~T} 3)$ & $300(\mathrm{~T} 4)$ & 330 (T5) & 360 (T6) \\
\hline \multirow{7}{*}{$0-21 d$} & Crude protein & 22.90 & 22.95 & 23.10 & 22.93 & 22.79 & 22.89 \\
\hline & Crude fat & 5.29 & 5.26 & 5.44 & 5.54 & 5.46 & 5.66 \\
\hline & Calcium & 1.01 & 1.02 & 1.04 & 1.01 & 1.02 & 1.03 \\
\hline & Phosphorus & 0.82 & 0.83 & 0.89 & 0.81 & 0.83 & 0.82 \\
\hline & Sodium & 0.14 & 0.22 & 0.29 & 0.36 & 0.43 & 0.51 \\
\hline & Potassium & 0.82 & 0.87 & 0.92 & 0.97 & 1.02 & 1.07 \\
\hline & Chloride & 0.23 & 0.28 & 0.33 & 0.38 & 0.43 & 0.48 \\
\hline \multirow{7}{*}{$22-35 d$} & Crude protein & 21.78 & 21.67 & 21.84 & 21.79 & 21.66 & 21.85 \\
\hline & Crude fat & 4.24 & 4.20 & 4.15 & 4.11 & 4.21 & 4.09 \\
\hline & Calcium & 1.03 & 0.94 & 0.94 & 0.95 & 0.96 & 0.96 \\
\hline & Phosphorus & 0.78 & 0.77 & 0.78 & 0.78 & 0.78 & 0.78 \\
\hline & Sodium & 0.16 & 0.23 & 0.29 & 0.37 & 0.44 & 0.52 \\
\hline & Potassium & 0.83 & 0.85 & 0.89 & 0.95 & 0.99 & 1.04 \\
\hline & Chloride & 0.25 & 0.27 & 0.32 & 0.37 & 0.42 & 0.47 \\
\hline
\end{tabular}

Table 2. Effect of varying dietary electrolyte balance on overall performance of heat-stressed broiler chickens.

\begin{tabular}{|c|c|c|c|c|c|c|c|}
\hline Periods & $\begin{array}{c}\mathrm{DEB} \\
\mathrm{mEq} / \mathrm{Kg}\end{array}$ & $\begin{array}{c}\text { FI } \\
\text { (g/bird) }\end{array}$ & $\begin{array}{c}\text { BWG } \\
\text { (g/bird) }\end{array}$ & FCR $(g / g)$ & $\begin{array}{l}\text { Protein } \\
\text { intake } \\
\text { (g/bird) }\end{array}$ & PER & $\begin{array}{c}\text { Mortality } \\
\text { (\%) }\end{array}$ \\
\hline \multirow{6}{*}{$0-35 d$} & $210(\mathrm{~T} 1)$ & 2398.96 & $1273.80^{c}$ & $1.89^{\mathrm{a}}$ & 551.76 & $2.31^{\mathrm{c}}$ & 0.00 \\
\hline & 240 (T2) & 2429.90 & $1448.54^{\mathrm{a}}$ & $1.69^{\mathrm{b}}$ & 558.88 & $2.59^{\mathrm{a}}$ & 0.00 \\
\hline & 270 (T3) & 2393.28 & $1417.80^{\mathrm{ab}}$ & $1.69^{\mathrm{b}}$ & 550.45 & $2.58^{\mathrm{a}}$ & 0.00 \\
\hline & $300(\mathrm{~T} 4)$ & 2353.95 & $1346.54^{\mathrm{b}}$ & $1.75^{\mathrm{ab}}$ & 541.41 & $2.49^{\mathrm{b}}$ & 2.00 \\
\hline & 330 (T5) & 2407.82 & $1320.10^{\mathrm{bc}}$ & $1.82^{\mathrm{ab}}$ & 553.80 & $2.38^{\mathrm{bc}}$ & 0.00 \\
\hline & 360 (T6) & 2414.74 & $1309.29^{\mathrm{bc}}$ & $1.85^{\mathrm{a}}$ & 555.39 & $2.36^{\mathrm{c}}$ & 4.00 \\
\hline SEM & & 59.73 & 39.22 & 0.05 & 13.74 & 0.06 & 1.29 \\
\hline$P$ value & & 0.97 & 0.03 & 0.02 & 0.97 & 0.02 & 0.18 \\
\hline
\end{tabular}

${ }_{\text {abc Means for treatments within a column with no common superscript showed significant }(\mathrm{P}<0.05) \text { differ- }}$ ences using DMRT. FI-Feed intake, BWG-Body weight gain, FCR-Feed conversion ratio, PER-Protein efficiency ratio, DEB - Dietary electrolyte balance, $\mathrm{P}$ value-Probability value, SEM-Standard error of means.

$(\mathrm{P}>0.05)$ affected by varying dietary electrolyte balance and values ranged from $2353.95 \mathrm{~g}$ (T4) to 2429.90 (T2). However, body weight gain observed in birds on T2 (1448.54 g) was significantly $(\mathrm{P}<0.05)$ higher compared to T1 (1273.80), T4 (1346.54), T5 (1320.10) and T6 (1309.29 g), but did not differ significantly (P > $0.05)$ from T3 (1417.80 g). Feed conversion ratio in T1 (1.89) and T6 (1.85) were 
similar to T4 (1.75) and T5 (1.82) but were significantly $(\mathrm{P}<0.05)$ higher compared to T2 (1.69) and T3 (1.69) at 0 to 35 days. Protein intake values of heat-stressed broiler chickens were not significantly affected by different dietary electrolyte balance, and values ranged from 541.41 (T4) to $558.88 \mathrm{~g}$ (T2). However, protein efficiency ratio (PER) observed in birds on T2 (2.59) and T3 (2.58) were significantly $(\mathrm{P}<0.05)$ higher compared to other treatments. However, T1 (2.31) and T6 (2.36) had the lowest PER. Mortality was not significantly $(P>0.05)$ affected by varying $\mathrm{DEB}$, and values ranged from 0.00 in $\mathrm{T} 1, \mathrm{~T} 2, \mathrm{~T} 3$, and $\mathrm{T} 5$ to 4.00 (T6).

\subsection{Carcass Yield of Heat-Stressed Broilers at 35 Days}

Table 3 shows the carcass characteristics of heat-stressed broilers fed varying levels of aggregate $\mathrm{DEB}$ at 35 days. It was observed that there were no significant $(\mathrm{P}>0.05)$ differences in the live and bled weights of heat-stressed birds on varying DEB and values ranged from 1322.80 (T6) to $1457.20 \mathrm{~g}$ (T3); and 1189.20 (T6) to 1336.80 (T3), respectively. However, defeathered weight of birds on T3 (1293.20) was significantly $(\mathrm{P}<0.05)$ higher compared to T6 $(1149.80 \mathrm{~g})$, but was similar to other dietary treatments. Higher $(\mathrm{P}<0.05)$ dressed weight was observed in birds on T3 (1162.80), T4 (1121.60) and T5 (1104.00) compared to T6 (1022.20). The head, neck, drumstick, back, and shank were not significantly $(\mathrm{P}>0.05)$ affected by varying DEB at 35 days. Birds on T6 (101.80) had the lowest $(\mathrm{P}<0.05)$ thigh weight. The highest $(\mathrm{P}<0.05)$ weight of wings was observed in birds on $\mathrm{T} 2$ $(123.40 \mathrm{~g})$ and was significantly $(\mathrm{P}<0.05)$ higher compared to T1 (108.00), T5 (107.60) and T6 (106.00 g). The highest $(\mathrm{P}<0.05)$ breast meat weight was observed in birds on T3 (325.60) compared to T1 (260.00), T5 (283.60), and T6 $(273.40 \mathrm{~g})$, but did not differ significantly $(\mathrm{P}>0.05)$ from other dietary treatments. The highest $(\mathrm{P}<0.05)$ tail weight was observed in birds on $\mathrm{T} 3(11.60$ g).

Table 3. Carcass characteristics of heat-stressed broiler chickens fed levels of dietary electrolyte balance at 35 days.

\begin{tabular}{|c|c|c|c|c|c|c|c|c|c|c|c|c|c|}
\hline $\begin{array}{c}\mathrm{DEB} \\
\mathrm{mEq} / \mathrm{Kg}\end{array}$ & $\begin{array}{c}\text { Live } \\
\text { weight }(\mathrm{g})\end{array}$ & $\begin{array}{c}\text { Bled } \\
\text { weight }(g)\end{array}$ & $\begin{array}{c}\text { DF } \\
\text { weight (g) }\end{array}$ & $\begin{array}{l}\text { DW } \\
(\mathrm{g})\end{array}$ & $\begin{array}{l}\text { Head } \\
(\mathrm{g})\end{array}$ & $\begin{array}{c}\text { Neck } \\
\text { (g) }\end{array}$ & $\begin{array}{l}\text { Thigh } \\
\text { (g) }\end{array}$ & $\begin{array}{l}\text { Ds } \\
\text { (g) }\end{array}$ & $\begin{array}{l}\text { Wings } \\
\text { (g) }\end{array}$ & $\begin{array}{l}\text { BM } \\
(\mathrm{g})\end{array}$ & $\begin{array}{l}\text { Back } \\
\text { (g) }\end{array}$ & $\begin{array}{l}\text { Shank } \\
(\mathrm{g})\end{array}$ & $\begin{array}{l}\text { Tail } \\
\text { (g) }\end{array}$ \\
\hline $210(\mathrm{~T} 1)$ & 1346.00 & 1260.20 & $1210.40^{\mathrm{ab}}$ & $1082.20^{\mathrm{ab}}$ & 45.20 & 68.00 & $141.20^{\mathrm{a}}$ & 121.80 & $108.00^{\mathrm{b}}$ & $260.00^{\mathrm{b}}$ & 159.60 & 57.60 & $10.40^{\mathrm{ab}}$ \\
\hline 240 (T2) & 1456.40 & 1335.60 & $1227.00^{\mathrm{ab}}$ & $1094.20^{\mathrm{ab}}$ & 43.20 & 60.80 & $127.60^{\mathrm{a}}$ & 132.20 & $123.40^{\mathrm{a}}$ & $290.20^{\mathrm{ab}}$ & 178.20 & 64.20 & $9.40^{\mathrm{b}}$ \\
\hline 270 (T3) & 1457.20 & 1336.80 & $1293.20^{\mathrm{a}}$ & $1162.80^{\mathrm{a}}$ & 46.60 & 66.80 & $144.60^{\mathrm{a}}$ & 129.00 & $117.60^{\mathrm{ab}}$ & $325.60^{\mathrm{a}}$ & 191.60 & 61.60 & $11.60^{\mathrm{a}}$ \\
\hline $300(\mathrm{~T} 4)$ & 1416.50 & 1301.60 & $1249.80^{\mathrm{ab}}$ & $1121.60^{\mathrm{a}}$ & 45.20 & 63.00 & $126.60^{\mathrm{a}}$ & 139.20 & $115.20^{\mathrm{ab}}$ & $291.80^{\mathrm{ab}}$ & 175.40 & 65.40 & $9.80^{\mathrm{b}}$ \\
\hline 330 (T5) & 1370.40 & 1286.20 & $1230.00^{\mathrm{ab}}$ & $1104.00^{\mathrm{a}}$ & 46.80 & 65.80 & $133.40^{\mathrm{a}}$ & 129.60 & $107.60^{\mathrm{b}}$ & $283.60^{\mathrm{b}}$ & 182.00 & 60.80 & $9.80^{\mathrm{b}}$ \\
\hline 360 (T6) & 1322.80 & 1189.20 & $1149.80^{\mathrm{b}}$ & $1022.20^{\mathrm{b}}$ & 38.00 & 60.40 & $101.80^{\mathrm{b}}$ & 133.00 & $106.00^{\mathrm{b}}$ & $273.40^{\mathrm{b}}$ & 171.80 & 56.20 & $9.40^{\mathrm{b}}$ \\
\hline SEM & 45.81 & 45.81 & 36.78 & 36.54 & 2.71 & 4.10 & 6.85 & 6.28 & 5.23 & 15.56 & 13.01 & 3.28 & 0.62 \\
\hline P Value & 0.22 & 0.24 & 0.19 & 0.19 & 0.24 & 0.69 & 0.00 & 0.54 & 0.17 & 0.11 & 0.65 & 0.34 & 0.15 \\
\hline
\end{tabular}

${ }^{\mathrm{ab}}$ Means for treatments within a column with no common superscript showed significant $(\mathrm{P}<0.05)$ differences using DMRT. DEB-Dietary electrolyte balance, DF-Defeathered, DW-Dressed weight, Ds—Drumstick, BM-Breast meat, SEM-Standard error of means, $\mathrm{P}$ value-Probability. 
Table 4 shows the organ weights and abdominal fat content of heat-stressed broiler chickens fed diets with varying electrolyte balance. The lungs, kidney, spleen and heart of broiler chickens were not significantly $(P>0.05)$ affected by varying DEB, and values ranged from 5.80 to $8.00 \mathrm{~g} ; 7.20$ to $9.00 \mathrm{~g} ; 1.40$ to $2.00 \mathrm{~g}$; and 8.20 to $10.80 \mathrm{~g}$, respectively. However, birds on T3 (36.60) and T6 (34.40 g) had the lowest $(\mathrm{P}<0.05)$ liver weight compared to other dietary treatments. Birds on T1 (41.60 g) had significantly $(\mathrm{P}<0.05)$ higher eviscerated gizzard weight compared to T2 (32.60), T3 (35.60), T5 (33.60) and T6 (34.20 g). Higher ( $\mathrm{P}<$ $0.05)$ abdominal fat content was observed in birds on T3 (11.60) and T4 (11.40) compared to other dietary treatments.

Figure 1 shows the relationship of varying dietary electrolyte balance with protein efficiency ratio of broiler chickens under severe heat stress condition. An optimum dietary protein efficiency was observed at a DEB range of 270 to 280 $\mathrm{mEq} / \mathrm{kg}$. The $\mathrm{R}^{2}$ value (0.65) indicated that about $65 \%$ of the observed changes in dietary protein efficiency were as a result of dietary electrolyte balance.

\subsection{Cost-Benefit Analysis of Feeding Dietary Electrolytes to Heat-Stressed Broilers}

Table 5 shows the economic implication of feeding dietary electrolytes to heatstressed broiler chickens over a period of 35 days. Feed cost per kilogram was significantly $(\mathrm{P}<0.05)$ higher in T6 $(157.50)$ compared to other dietary treatments. Feed cost per kilogram decreases with decreasing dietary electrolyte balance, with the lowest $(\mathrm{P}<0.05)$ value observed in T1 with inherent DEB of 210 $\mathrm{mEq} / \mathrm{kg}$ only. However, feed cost per bird was significantly $(\mathrm{P}<0.05)$ higher in T6 ( $\$ 380.28)$ compared to T1 ( $\$ 343.36)$, but did not differ $(\mathrm{P}>0.05)$ from other dietary treatments. The feed cost per kilogram weight gain differed significantly $(\mathrm{P}<0.05)$ in heat-stressed broilers fed different DEB. The lowest $(\mathrm{P}<0.05)$ feed cost values per kilogram weight gain were observed in T2 ( $\$ 247.37)$ and T3 ( $\$ 251.06)$, while the highest $(\mathrm{P}<0.05)$ value was observed in T6 ( $\$ 291.11)$, and did not differ significantly ( $\mathrm{P}>0.05)$ from T5 ( $\$ 281.35$ ).

Table 4. Organ weights and abdominal fat content of heat-stressed broiler chickens fed varying levels of dietary electrolyte balance at 35 days.

\begin{tabular}{cccccccc}
\hline $\begin{array}{c}\mathrm{DEB} \\
\mathrm{mEq} / \mathrm{Kg}\end{array}$ & $\begin{array}{c}\text { Lungs } \\
(\mathrm{g})\end{array}$ & $\begin{array}{c}\text { Liver } \\
(\mathrm{g})\end{array}$ & $\begin{array}{c}\text { Eviscerated } \\
\text { gizzard }(\mathrm{g})\end{array}$ & $\begin{array}{c}\text { Kidney } \\
(\mathrm{g})\end{array}$ & $\begin{array}{c}\text { Spleen } \\
(\mathrm{g})\end{array}$ & $\begin{array}{c}\text { Heart } \\
(\mathrm{g})\end{array}$ & $\begin{array}{c}\text { Abdominal } \\
\text { fat }(\mathrm{g})\end{array}$ \\
\hline $\mathbf{2 1 0}(\mathrm{T} 1)$ & 7.20 & $41.4^{\mathrm{ab}}$ & $41.60^{\mathrm{a}}$ & 9.00 & 1.40 & 8.20 & $8.80^{\mathrm{b}}$ \\
$\mathbf{2 4 0}(\mathrm{T} 2)$ & 6.20 & $43.00^{\mathrm{a}}$ & $32.60^{\mathrm{b}}$ & 6.60 & 2.00 & 8.80 & $8.80^{\mathrm{b}}$ \\
$\mathbf{2 7 0}(\mathrm{T} 3)$ & 5.80 & $36.60^{\mathrm{c}}$ & $35.60^{\mathrm{b}}$ & 8.40 & 1.80 & 9.00 & $11.60^{\mathrm{a}}$ \\
$\mathbf{3 0 0}(\mathrm{T} 4)$ & 8.00 & $40.40^{\mathrm{b}}$ & $37.00^{\mathrm{ab}}$ & 7.20 & 2.00 & 8.20 & $11.40^{\mathrm{a}}$ \\
$\mathbf{3 3 0}(\mathrm{T} 5)$ & 6.80 & $41.20^{\mathrm{ab}}$ & $33.60^{\mathrm{b}}$ & 8.40 & 1.80 & 9.20 & $9.00^{\mathrm{b}}$ \\
$\mathbf{3 6 0}(\mathrm{T} 6)$ & 6.20 & $34.40^{\mathrm{c}}$ & $34.20^{\mathrm{b}}$ & 7.40 & 1.80 & 10.80 & $7.80^{\mathrm{b}}$ \\
SEM & 0.83 & 1.93 & 2.46 & 0.86 & 0.31 & 0.81 & 1.37 \\
P Value & 0.46 & 0.03 & 0.16 & 0.39 & 0.78 & 0.26 & 0.29 \\
\hline
\end{tabular}

${ }^{\mathrm{abc}}$ Means for treatments within a column with no common superscript showed significant $(\mathrm{P}<0.05)$ differences using DMRT. SEM-Standard error of mean, P Value-Probability, DEB-Dietary electrolyte balance. 
Table 5. Cost-benefit analysis of heat-stressed broiler chickens fed diets with varying electrolyte balance.

\begin{tabular}{|c|c|c|c|c|c|c|}
\hline \multirow{2}{*}{ Periods } & \multirow{2}{*}{$\begin{array}{c}\mathrm{DEB} \\
\mathrm{mEq} / \mathrm{Kg}\end{array}$} & \multirow{2}{*}{$\begin{array}{c}\text { FI } \\
\text { (g/bird) }\end{array}$} & \multirow{2}{*}{$\begin{array}{l}\text { BWG } \\
\text { (g/bird) }\end{array}$} & \multirow{2}{*}{$\begin{array}{l}\text { Feed Cost per } \\
\text { kilogram (A) }\end{array}$} & \multirow{2}{*}{$\begin{array}{c}\text { Feed Cost } \\
\text { per bird ( })\end{array}$} & \multirow{2}{*}{$\begin{array}{c}\text { Feed Cost per } \\
\text { weight gain } \\
\text { (\#) }\end{array}$} \\
\hline & & & & & & \\
\hline \multirow{6}{*}{$0-35 d$} & $210(\mathrm{~T} 1)$ & 2398.96 & $1273.80^{c}$ & $143.10^{\mathrm{f}}$ & $343.36^{\mathrm{b}}$ & $270.52^{\mathrm{b}}$ \\
\hline & $240(\mathrm{~T} 2)$ & 2429.90 & $1448.54^{\mathrm{a}}$ & $146.80^{\mathrm{e}}$ & $356.28^{\mathrm{ab}}$ & $247.37^{c}$ \\
\hline & 270 (T3) & 2393.28 & $1417.80^{\mathrm{ab}}$ & $148.90^{\mathrm{d}}$ & $356.72^{\mathrm{ab}}$ & $251.06^{\mathrm{c}}$ \\
\hline & 300 (T4) & 2353.95 & $1346.54^{\mathrm{b}}$ & $152.10^{c}$ & $358.09^{\mathrm{ab}}$ & $266.19^{\mathrm{bc}}$ \\
\hline & 330 (T5) & 2407.82 & $1320.10^{\mathrm{bc}}$ & $154.20^{\mathrm{b}}$ & $371.35^{\mathrm{ab}}$ & $281.35^{\mathrm{ab}}$ \\
\hline & 360 (T6) & 2414.74 & $1309.29^{\mathrm{bc}}$ & $157.50^{\mathrm{a}}$ & $380.28^{\mathrm{a}}$ & $291.11^{\mathrm{a}}$ \\
\hline SEM & & 59.73 & 39.22 & 0.00 & 9.15 & 6.89 \\
\hline$P$ value & & 0.97 & 0.03 & $<0.0001$ & 0.11 & 0.001 \\
\hline
\end{tabular}

${ }^{\mathrm{abc}}$ Means for treatments within a column with no common superscript showed significant $(\mathrm{P}<0.05)$ differences using DMRT. One US Dollar at the trial period was equivalent to $\$ 360.00$, SEM-Standard error of mean, P Value-Probability, DEB-Dietary electrolyte balance.

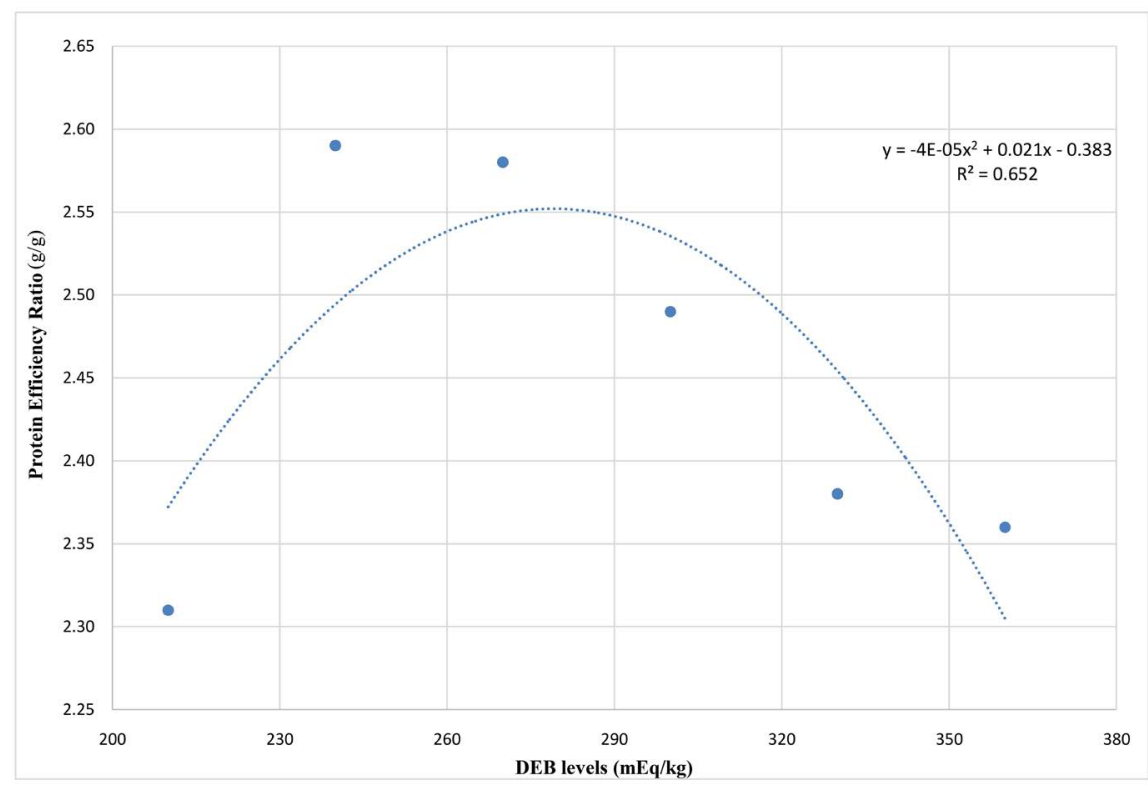

Figure 1. Relationship of varying dietary electrolyte balance (DEB) with protein efficiency ratio of broiler chickens under severe heat stress condition.

\section{Discussion}

A viable nutritional approach to solving heat stress in poultry industry is that which critically considers the birds' health, overall performance, meat safety and economical carcass yield. The results of present study on mortality are consistent with the report of Borges et al. (2003) [24] who observed no significant effects of DEB treatments $(0,120,240,360 \mathrm{mEq} / \mathrm{Kg})$ on mortality in broilers reared under moderately high ambient temperature and relative humidity. Contrastingly, the authors also noted non-significant effects of DEB on carcass yield, breast, thigh 
plus leg, wing, and abdominal fat in broilers grown to $42 \mathrm{~d}$ of age. Mitchell and Kettlewell (1998) [25] reported that heat stress during transport has been associated with higher mortality rate, decreased meat quality, and reduced welfare status. Warriss et al. (2005) [26] demonstrated a seasonal impact with peak mortality rates of broilers occurring in the summer months with relatively higher environmental temperatures. The results of present study on differences in protein utilization could have been as a result of excessive increase in metabolic cations and anions from electrolytes and amino acids, with resultant effect of blood ionic disorder (alkalosis or acidosis) (Popoola et al., 2020) [20] and increased body temperature (Popoola et al., 2020) [15]. Ahmad et al. (2005) [18] reported that different sources of DEB rations increased significantly, the carcass weights; and supported the findings of current study. Ahmad et al. (2005) [18] also noted larger sizes of the proventriculus and gizzard which may have improved the digestive capacity and higher dressing percentage, breast meat and thigh of birds on electrolyte-supplemented diets. However, contrasting results from some researches might be due to differences in experimental periods, feed formulation, and severity of heat stress. Pourreza and Edriss (1992) [27] reared broilers at $20^{\circ} \mathrm{C}$ to $30^{\circ} \mathrm{C}$ and noticed that heat stress decreased slaughter, carcass, and abdominal fat weight. However, Johnson and Karunajeewa (1985) [28] and Borges et al. (1999) [29] observed no effect on carcass and abdominal fat yield with different DEB treatments under normal environmental condition. Hooge (2003) [30] noted that gizzard weight was increased linearly with increasing levels of dietary sodium $(\mathrm{Na})$ and this increase reflects the increasing digestive or metabolic capacity of birds. Kidney weight was almost double the lowest level of dietary $\mathrm{Na}$ in the case of $\mathrm{NaHCO}_{3}$ when compared with the lowest level of $\mathrm{Na}_{2} \mathrm{SO}_{4}$. According to the author, bicarbonate buffer system mainly determines blood acid-base balance for optimal production performance and functions under regulatory control of the kidneys. However, from current study, aggregate dietary electrolyte balance ( 210 to $360 \mathrm{mEq} / \mathrm{kg}$ ) enhanced bicarbonate buffer system and exert no significant effect on kidney weight as Carew et al (2005) [31] opined that kidney weight is indicative of broiler dietary nutrient insufficiencies or the presence of anti-nutritional factors (Farran et al., 2005) [32]. Mushtaq et al. (2014) [33] reported that acid base imbalance might cause the higher kidney weight as the authors observed that a linear increase in dietary sodium decreased spleen weight and influenced bursa weight. Niu et al. (2009) [34] reported reduced lymphoid organ weights in broilers subjected to heat stress conditions. Felver-Gant et al. (2012) [35] observed reduced liver weights, though in laying hens subjected to chronic heat stress conditions. Bartlett and Smith (2003) [36] observed that broilers subjected to heat stress had lower levels of total circulating antibodies, as well as lower specific IgM and IgG levels, at primary and secondary humoral responses, with observed reduction in weights of the thymus, bursa, spleen, and liver.

Fewer reports exist on the effect of heat stress on intestinal microbial ecosystem of poultry and ruminants. Among such, is the report indicating that heat 
stress affected the microbial composition as well as the concentration of short-chain fatty acids in the rumen (Uyeno et al., 2010) [37], which is a much more complex microbial system in comparison to the poultry intestinal microbiota. Therefore, it is reasonable to assume that heat stress would also affect the intestinal microbial populations of poultry. Also, altered morphology, as well as changes in the microbial community structure in the intestinal tract of broilers subjected to heat stress have been reported (Burkholder et al., 2008) [38]. Oxidative stress begins the intestinal permeability dysfunctional process because under conditions of heat stress, higher concentrations of reactive oxygen species (ROS) are observed and result to increased intestinal permeability, which in turn facilitates the translocation of bacteria from the intestinal tract. For example, increased inflammation and translocation of Salmonella in broilers subjected to heat stress has been reported, resulting in increased levels of the pathogen in spleen sample (Quinteiro-Filho et al., 2010) [39]. The efficient balance of dietary electrolytes in present study has showcased corrections in intestinal permeability dysfunctional process, judging from the reference points of no mortality records, higher carcass yield and behavioral responses exhibited during the feeding trial under chronic heat stress condition. Therefore, it is assumed that the translocation of bacteria from the intestinal tract was hampered by heat stress-mitigating effect of electrolyte balanced rations as showcased in no visible occurrence of Salmonella in faecal output.

From current study, feed cost values per kilogram weight gain observed in diets with $240 \mathrm{mEq} / \mathrm{kg}$ and $270 \mathrm{mEq} / \mathrm{kg} \mathrm{DEB}$ were lower compared to other treatments and showcased promising economic buoyancy to both rural and commercial poultry farmers. An adoption of these dietary manipulations would sustain animal protein security in both developed and developing communities, while ensuring a high food safety standard under the changing climatic conditions prevalent in tropical regions. The effects of DEB on broiler performance are diverse and depend on differences in basal diet, broiler strain, temperature of rearing and supplemented electrolyte salts. However, these differences occurred because most researches have not taken into consideration the concept of aggregate DEB as described by Popoola et al. (2020) [20] which ensured the prevention of monovalent mineral toxicity in diets and serum of broiler chickens.

\section{Conclusion}

Electrolyte-balanced diets though contained salts that presumably could have improved satiety, yet they do not enhance appetite in heat-stressed broilers. However, dietary protein efficiency was enhanced at an electrolyte balance levels of 240 and $270 \mathrm{mEq} / \mathrm{kg}$, which translated into increased body weight gain. Weights of primal cut of birds on $270 \mathrm{mEq} / \mathrm{kg}$ DEB were highest at 35 days. Feed cost values per kilogram weight gain in diets with $240 \mathrm{mEq} / \mathrm{kg}$ and $270 \mathrm{mEq} / \mathrm{kg}$ DEB were lower and showcased promising economic buoyancy to poultry farmers, while ensuring a high food safety standard under tropical conditions. 


\section{Acknowledgements}

The profound moral and financial supports of Engr. and Mrs M. O. A Popoola are hereby acknowledged.

\section{Contribution of Authors}

I. O. Popoola designed the experiment, analyzed data and drafted the manuscript. O. R. Popoola assisted in data collection and literature search, A. A. Adeyemi, O. M. Ojeniyi, I. F. Olaleru, F. J. Oluwadele and E. O. Akinwumi contributed and approved the final draft of manuscript.

\section{Conflicts of Interest}

The authors declare no conflicts of interest regarding the publication of this paper.

\section{References}

[1] Ojo, S.O. (2003) Productivity and Technical Efficiency of Poultry Egg Production in Nigeria. International Journal of Poultry Science, 2, 459-464. https://doi.org/10.3923/ijps.2003.459.464

[2] Ohajianya, D.O., Mgbada, J.U., Onu, P.N., Enyia, C.O., Henri-Ukoha, A., BenChendo, N.G. and Godson-Ibeji, C.C. (2013) Technical and Economic Efficiencies in Poultry Production in Imo State, Nigeria. American Journal of Experimental Agriculture, 3, 927-938. https://doi.org/10.9734/AJEA/2013/4089

[3] Muriu, J.I., Njoka-Njiri, E.N., Tuitoek, J.N. and Nanua, J.N. (2002) Evaluation of Sorghum (Sorghum bicolor) as Replacement of Maize in the Diet of Growing Rabbit (Oryctolagus cuniculus). Asian-Australasian Journal of Animal Science, 15, 565-569. https://doi.org/10.5713/ajas.2002.565

[4] Oyewole, B.O., Olarenwaju, G. and Dafwang, I.I. (2013) Performance of Broilers Fed Premix Prepared from Locally Sourced Materials. Standard Research Journal of Agricultural Science, 1, 17-20.

[5] St-Pierre, N.R., Cobanov, B. and Schnitkey, G. (2003) Economic Losses from Heat Stress by US Livestock Industries. Journal of Dairy Science, 86, E52-E77. https://doi.org/10.3168/jds.S0022-0302(03)74040-5

[6] Rostagno, M.H. (2009) Can Stress in Farm Animals Increase Food Safety Risk? Foodborne Pathogens and Disease, 6, 767-776. https://doi.org/10.1089/fpd.2009.0315

[7] Verbrugghe, E., Boyen, F., Gaastra, W., Bekhuis, L., Leyman, B., Van Paryz, A., Haesebrouck, F. and Pasmans, F. (2012) The Complex Interplay between Stress and Bacterial Infections in Animals. Veterinary Microbiology, 155, 115-127. https://doi.org/10.1089/fpd.2009.0315

[8] Sohail, M.U., Hume, M.E., Byrd, J.A., Nisbet, D.J., Ijaz, A., Sohail, A., Shabbir, M.Z. and Rehman, H. (2012) Effect of Supplementation of Prebiotic Mannan-Oligosaccharides and Probiotic Mixture on Growth Performance of Broilers Subjected to Chronic Heat Stress. Poultry Science, 91, 2235-2240. https://doi.org/10.3382/ps.2012-02182

[9] Geraert, P.A., Padilha, J.C. and Guillaumin, S. (1996) Metabolic and Endocrine Changes Induced by Chronic Heat Exposure in Broiler Chickens: Biological and Endocrinological Variables. British Journal of Nutrition, 75, 205-216.

https://doi.org/10.1079/BJN19960125 
[10] Lu, Q., Wen, J. and Zhang, H. (2007) Effect of Chronic Heat Exposure on Fat Deposition and Meat Quality in Two Genetic Types of Chicken. Poultry Science, 86, 1059-1064. https://doi.org/10.1093/ps/86.6.1059

[11] Imik, H., Atasever, M.A., Urgar, S., Ozlu, H., Gumus, R. and Atasever, M. (2012) Meat Quality of Heat Stress Exposed Broilers and Effect of Protein and Vitamin E. British Poultry Science, 53, 689-698. https://doi.org/10.1080/00071668.2012.736609

[12] Zhang, Z.Y., Jia, G.Q., Zuo, J.J., Zhang, Y., Lei, J., Ren, L. and Feng, D.Y. (2012) Effects of Constant and Cyclic Heat Stress on Muscle Metabolism and Meat Quality of Broiler Breast Fillet and Thigh Meat. Poultry Science, 91, 2931-2937. https://doi.org/10.3382/ps.2012-02255

[13] Lyte, M. (2004) Microbial Endocrinology and Infectious Disease in the 21st Century. Trends in Microbiology, 12, 14-20. https://doi.org/10.1016/j.tim.2003.11.004

[14] Freestone, P.P.E., Sandrini, S.M., Haigh, R.D. and Lyte, M. (2008) Microbial Endocrinology: How Stress Influences Susceptibility to Infection. Trends in Microbiology, 16, 55-64. https://doi.org/10.1016/j.tim.2007.11.005

[15] Popoola, I.O., Popoola, O.R., Olajide, O.O., Adeyemi, A.A. and Alegbejo, Q.T. (2020b) Reducing Sharp Fluctuations in Body Temperature and Optimizing Production Index of Broilers Using Dietary Electrolytes. Open Journal of Animal Sciences, 10, 266-277. https://doi.org/10.4236/ojas.2020.102015

[16] Mongin, P. (1981) Recent Advances in Dietary Cation Anion Balance: Applications in Poultry. Proceedings of the Nutrition Society, 40, 285-294. https://doi.org/10.1079/PNS19810045

[17] Borges, S.A. (2001) Balanco eletrolitico e sua interrelacao com o equilibrio acidobase em frangos de corte submetidos a estresse calorico. Jaboticabal. Tese (Doutorado em Zootecnia) curso de posgraduacao em Zootecnia, Universidade Estadual Paulista, 97.

[18] Ahmad, T., Sarwar, M., Mahr-un-nisa, Ahsan-ul-haq and Zia-ul-hasan (2005) Influence of Varying Sources of Dietary Electrolytes on the Performance of Broilers Reared in a High Temperature Environment. Animal Feed Science and Technology, 20, 277-298. https://doi.org/10.1016/j.anifeedsci.2005.02.028

[19] Popoola, I.O. and Iyayi, E.A. (2018) Response of Heat-Stressed Broiler Chicks to Varying Dietary Electrolyte Balance at Pre-Starter and Starter Phases. Proceeding of 43 rd Annual Conference of the Nigerian Society for Animal Production, Owerri, 18-22 March 2018, 189-191.

[20] Popoola, I.O., Popoola, O.R., Ojeniyi, M.O., Olajide, O.O. and Iyayi, E.A. (2020) The Roles of Key Electrolytes in Balancing Blood Acid-Base and Nutrient in Broiler Chickens Reared under Tropical Conditions. Natural Science, 12, 4-11. https://doi.org/10.4236/ns.2020.121002

[21] Popoola, I.O., Oshibanjo, D.O., Popoola, O.R., Okuneye, T.A., Ilaboya, I.I. and Iyayi, E.A. (2019) Effect of Dietary Electrolyte Balance on Water Intake, Litter Moisture and Production of Broiler Chicks at Pre-Starter and Starter Phases. Open Journal of Animal Sciences, 9, 472-480. https://doi.org/10.4236/ojas.2019.94036

[22] Lacroix, R.L., Keeney, D.R. and Welsh, L.M. (1970) Potentiometric Titration of Chloride in Plant Tissue Extracts Using the Chloride Ion Electrode. Communications in Soil Science and Plant Analysis, 1, 1-6. https://doi.org/10.1080/00103627009366233

[23] Statistical Analysis System (2012) SAS Users Guide: Statistics. SAS Institute Inc., Cary.

[24] Borges, S.A., Fischer Da Silva, A.V., Ariki, J., Hooge, D.M. and Cummings, K.R. 
(2003) Dietary Electrolyte Balance for Broiler Chickens under Moderately High Ambient Temperatures and Relative Humidities. Poultry Science, 82, 301-308. https://doi.org/10.1093/ps/82.2.301

[25] Mitchell, M.A. and Kettlewell, P.J. (1998) Physiological Stress and Welfare of Broiler Chickens in Transit: Solutions Not Problems! Poultry Science, 77, 1803-1814. https://doi.org/10.1093/ps/77.12.1803

[26] Warriss, P.D., Pagazaurtundua, A. and Brown, S.N. (2005) Relationship between Maximum Daily Temperature and Mortality of Broiler Chickens during Transport and Lairage. British Poultry Science, 46, 647-651. https://doi.org/10.1080/00071660500393868

[27] Pourreza, J. and Edriss, M.A. (1992) The Effects of High vs. Normal Temperatures on the Physical Characteristics of the Broilers Carcass. Journal of Agricultural Science and Technology, 1, 35-41.

[28] Johnson, R.J. and Karunajeewa, H. (1985) The Effects of Dietary Minerals and Electrolytes on the Growth and Physiology of the Young Chick. Journal of Nutrition, 115, 1680-1690. https://doi.org/10.1093/jn/115.12.1680

[29] Borges, S.A., Ariki, J., Martins, J.C.L. and De-Moraes, V.M.B. (1999) Potassium Chloride Supplementation in Heat Stressed Broilers. Revista Brasileira de Zoologia, 28, 313-319. https://doi.org/10.1590/S1516-35981999000200014

[30] Hooge, D.M. (2003) Practicalities of Using Dietary Sodium and Potassium Supplements to Improve Poultry Performance. Proceedings of Arkansas Nutrition Conference, Fayetteville, 19.

[31] Carew, S.N., Oluremi, O.I.A. and Wambutda, E.P. (2005) The Quality of Commercial Feeds in Nigeria: A Case Study of Feeds in Makurdi, Benue State. Nigeria Veterinary Journal, 26, 147-150. https://doi.org/10.4314/nvj.v26i1.3483

[32] Farran, M.T., Halaby, W.S., Barbour, G.W., Uwayjan, M.G., Sleiman, F.T. and Ashkarian, V.M. (2005) Effects of Feeding Ervil (Viciaervilia) Seeds Soaked in Water or Acetic Acid on Performance and Internal Organ Size of Broilers and Production and Egg Quality of Laying Hens. Poultry Science, 84, 1723-1728.

https://doi.org/10.1093/ps/84.11.1723

[33] Mushtaq, M.M.H., Parvin, R. and Kim, J. (2014) Carcass and Body Organ Characteristics of Broilers Supplemented with Dietary Sodium and Sodium Salts under a Phase Feeding System. Journal of Animal Science Technology, 56, 4. https://doi.org/10.1186/2055-0391-56-4

[34] Niu, Z.Y., Liu, F.Z., Yan, Q.L. and Li, W.C. (2009) Effects of Different Levels of Vitamin $\mathrm{E}$ on Growth Performance and Immune Responses of Broilers under Heat Stress. Poultry Science, 88, 2101-2107. https://doi.org/10.3382/ps.2009-00220

[35] Felver-Gant, J.N., Mack, L.A., Dennis, R.L., Eicher, S.D. and Cheng, H.W. (2012) Genetic Variations Alter Physiological Responses Following Heat Stress in 2 Strains of Laying Hens. Poultry Science, 91, 1542-1551. https://doi.org/10.3382/ps.2011-01988

[36] Bartlett, J.R. and Smith, M.O. (2003) Effects of Different Levels of Zinc on the Performance and Immunocompetence of Broilers under Heat Stress. Poultry Science, 82, 1580-1588. https://doi.org/10.1093/ps/82.10.1580

[37] Uyeno, Y., Sekiguchi, Y., Tajima, K., Takenaka, A., Kurihara, M. and Kamagata, Y. (2010) An rRNA-Based Analysis for Evaluating the Effect of Heat Stress on the Rumen Microbial Composition of Holstein Heifers. Anaerobe, 16, 27-33. https://doi.org/10.1016/j.anaerobe.2009.04.006

[38] Burkholder, K.M., Thompson, K.L., Einstein, M.E., Applegate, T.J. and Patterson, 
J.A. (2008) Influence of Stressors on Normal Intestinal Microbiota, Intestinal Morphology, and Susceptibility to Salmonella enteritidis Colonization in Broilers. Poultry Science, 87, 1734-1741. https://doi.org/10.3382/ps.2008-00107

[39] Quinteiro-Filho, W.M., Ribeiro, A., Ferraz-de-Paula, V., Pinheiro, M.L., Sakai, M., As, L.R., Ferreira, A.J. and Palermo-Neto, J. (2010) Heat Stress Impairs Performance Parameters, Induces Intestinal Injury, and Decreases Macrophage Activity in Broiler Chickens. Poultry Science, 89, 1905-1914.

https://doi.org/10.3382/ps.2010-00812 